\title{
Soil loss estimation and severity mapping using RUSLE model and GIS: a case study in Megech Watershed, Ethiopia
}

Legese Abebaw Getu ( $\square$ legeseabebaw08@gmail.com )

Gondar Agricultural Researh center https://orcid.org/0000-0002-7300-6249

Attila Nagy

University of Debrecen

Hailu Kendie Addis

Amhara regional Agricultural research Institute

\section{Research Article}

Keywords: Soil erosion, Severity mapping, RUSLE model, Megech watershed, Ethiopia

Posted Date: January 13th, 2022

DOI: https://doi.org/10.21203/rs.3.rs-1256356/v1

License: (c) (i) This work is licensed under a Creative Commons Attribution 4.0 International License.

Read Full License 


\title{
Soil loss estimation and severity mapping using RUSLE model and GIS: a case study in Megech Watershed, Ethiopia
}

\author{
Legese Abebaw Getu ${ }^{1,3 *}$, Attila Nagy ${ }^{3}$ and Hailu Kendie Addis ${ }^{2}$
}

\begin{abstract}
Background: Soil erosion is the most serious problem that affects economic development, food security, and ecosystem services which is the main concern in Ethiopia. This study focused on quantifying soil erosion rate and severity mapping of the Megech watershed for effective planning and decision-making processes to implement protection measures. The RUSLE model integrated with ArcGIS software was used to conduct the present study. The six RUSLE model parameters: erosivity, erodibility, slope length and steepness, cover management, and erosion control practices were used as input parameters to predict the average annual soil loss and identify erosion hotspots in the watershed.

Results: The RUSLE estimated 1,399,210 tons $\mathrm{yr}^{-1}$ total soil loss from the watershed with a mean annual soil loss of 32.84 tons ha-1 $\mathrm{yr}^{-1}$. The soil erosion rate was varied from 0.08 to greater than 500 tons ha-1 $\mathrm{yr}^{-1}$. A severity map with seven severity classes was created for 27 sub-watersheds: low (below 10), moderate (10-20), high (20-30), very high (30-35), severe (35-40), very severe (40-45) and extremely severe (above 45$)$ in which the values are in tons $\mathrm{ha}^{-1} \mathrm{yr}^{-1}$. The area coverage was $6.5 \%, 11.1 \%, 8.7 \%, 22 \%, 30.9 \%, 13.4 \%$, and $7.4 \%$ for low, moderate, high, very high, severe, very severe, and extremely severe erosion classes respectively.

Conclusion: About $82 \%$ of the watershed was found in more than the high-risk category which reflects the need for immediate land management action. This paper could be important for decision-makers to prioritize critical erosion hotspot areas for comprehensive and sustainable management of the watershed.
\end{abstract}

Keywords: Soil erosion, Severity mapping, RUSLE model, Megech watershed, Ethiopia

\section{Background}

Accelerated soil erosion creates many critical problems such as environmental, socio-economic [1], [2], land degradation, food security problems [3], intensifying climate change, increased conflict, and mass human migration [4]. It has been estimated that about $80-85 \%$ of agricultural land suffers from soil erosion and six million hectares of fertile land is being lost every year due to water erosion and other related factors [5]-[7]. Worldwide, soil erosion rate from cultivated land ranges from 22 to 100-ton ha- $\mathrm{yr}^{-1}$ and causing an annual

*Correspondence: legeseabebaw08@gmail.com

Gondar Agricultural Research Center, P.o. Box 1337, Gondar, Ethiopia

Full list of author information is available at the end of the article reduction in crop productivity and by $15-30 \%$ [8]. In mountainous agricultural lands, the annual rate of soil loss can be reached 400 tons ha ${ }^{-1}$ [9].

Sub-Saharan Africa (SSA) countries are highly threatened by broader land degradation problems, more specifically higher soil loss and crop nutrient depletion problems which abrupt sustainable agricultural production and aggravate food insecurity [10], [11]. Ethiopia, one of the SSA countries is facing severe soil degradation problems resulting in a decline in different soil functions and is the ultimate cause of an irreversible change on the poorly renewable soil resources [12]. In the Ethiopian highlands, soil erosion by water is extreme and reached its peak, and still exists a continuous loss of about 1.5 to 3.5 billion tons of fertile soil each year, of which $45 \%$ is initiated from agricultural land [13]-[16]. On plot-based experiment of long-term analysis of Soil 
Conservation Research Programme (SCRP), the average annual rate of soil erosion on cultivated lands was estimated approximately 40 tons $\mathrm{ha}^{-1} \mathrm{yr}^{-1}$ and it ranges from 1 ton $\mathrm{ha}^{-1} \mathrm{yr}^{-1}$ to more than 300 tons $\mathrm{ha}^{-1} \mathrm{yr}^{-1}$ [17]. Severe soil erosion on farmland which is about 100 tons $\mathrm{ha}^{-1} \mathrm{yr}^{-1}$ was reported by [18] and 42 tons $\mathrm{ha}^{-1}$ by [13].

Megech watershed, part of the Ethiopian highlands and Blue Nile River Basin (BNRB), is highly affected by soil erosion because of intensive rainfall coupled with human interventions, such as removal of vegetation cover for agricultural practices, the improper agricultural system, and wrong livestock management systems [17], [19]-[21]. This high rate of soil erosion in the watershed system can increase the downstream sedimentation problem, loss of onsite crop production, and water pollution in Lake Tana and other reservoirs found in the watershed. The most important domestic and irrigation water source dams; Angereb and Megech, can be possibly affected by sedimentation problems that arise from the upstream areas of the watershed. For example, one-third of the volume of the Angereb reservoir was filled with sedimentation in 2007 [19].

Tremendous efforts were intensively exerted in the Ethiopian highlands to implement and expand soil and water conservation practices to counteract the increasing impact of soil degradation [17]. Although such a huge capital and effort was exerted, the effectiveness of the installed conservation measures is still in doubt. Insufficiently assessing and identification of erosion hotspot areas and limitation of sub-watershed-based soil loss quantification results inadequate planning and design of conservation measures. Implementing conservation efforts at once at the watershed level is impossible. Before applying any protection measures, pre-assessment work on targeted watersheds such as identifying the root causes of soil erosion, quantifying the magnitude of soil loss as well as assessing the erosion hotspots is some of the key points to look for options to address the issues of soil degradation [17], [18]. Watershed and sub-watershed based spatial and temporal quantification of soil erosion and generation of severity map is from the first essential phase of an integrated watershed management plan to implement sustainable land management strategies and land use planning [22].

There are some studies related to soil erosion assessment at a basin scale, in the Lake Tana basin which included the study watershed [21], [23].
However, there was no sufficient study or time-limited regarding the rate of soil loss at the Megech watershed, and the erosion hotspots are not yet identified. Therefore, this research was initiated to assess and quantify the rate of soil loss and to create an erosion hotspot map in the entire Megech watershed which helps for feasible planning and right decision-making processes to implement watershed-based conservation programs.

\section{Materials and Methods Description of the study area}

The study was conducted in the Megech watershed, located on the north side of Lake Tana sub-basin in the Amhara region, Ethiopia (Fig. 1). Megech catchment is one of the main river catchments in the upper BNRB in which its altitude ranges from 1878 to $2978 \mathrm{~m}$ above mean sea level. The watershed covers about $427 \mathrm{~km}^{2}$ area and is geographically located between 12.49 to 12.76 North latitude and 37.41 to 37.63 East longitude. The catchment is characterized by mountainous, rugged, and steep-sloped topography that varies from $0^{\infty}$ to $68^{\circ}$. Two dams are constructed in the watershed, the older dam, Angereb which is used for supplying water for Gondar town, and the Megech dam which is being constructed at watershed downstream, will be used for both irrigation purposes and water supply for Gondar town.

According to [24], the Megech watershed falls in two agroclimatic zones so-called Dega (cool sub-humid) in the higher altitude areas and Weyna Dega (cool-humid) in low altitudes. The climate of the Megech watershed, generally for upper BNRB, shows tropical monsoon climate characteristics [25].

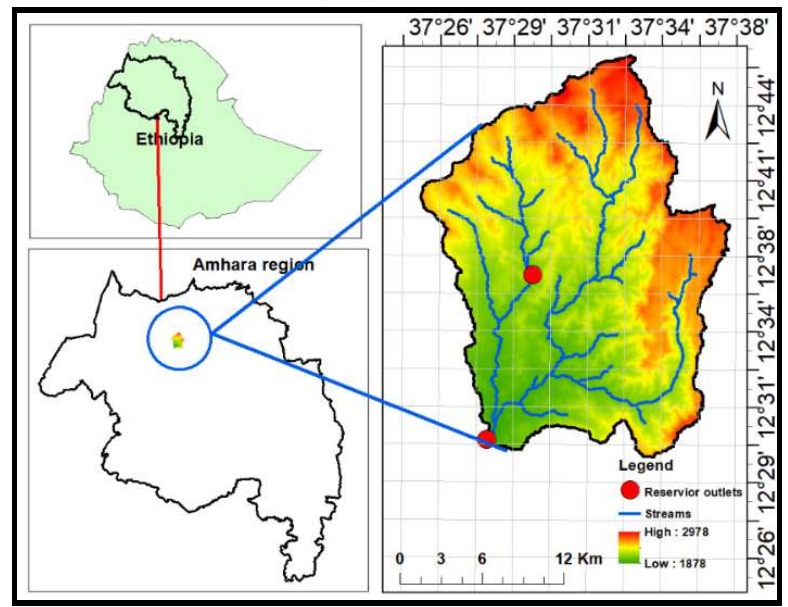

Fig. 1 Map of Megech watershed 
Rainfall distribution is varied from $1510 \mathrm{~mm}$ in the highlands to $710 \mathrm{~mm}$ in the lowland parts, with an average annual rainfall of about $1090 \mathrm{~mm}$. Nearly $80 \%$ of the rainfall occurs from June to September. The average maximum and minimum temperatures are about $27.3{ }^{\circ} \mathrm{C}$ and $13.5^{\circ} \mathrm{C}$ respectively [26]. The main soils in the watershed are Leptosols, Nitisols, Luvisols, and vertisols. Rainfed agriculture in a mixed farming system with cereals, pulses, oilseeds, spices, and livestock is practiced in the watershed [26].

\section{Data sources and analytical methods}

To estimate rainfall-driven soil loss and identify erosion hotspots of the watershed, various datasets from different sources were used. The annual rainfall data was obtained from Ethiopian National Meteorological Agency (NMA) to compute the erosivity factor. Rainfall data from 14 in/nearby weather stations were collected from 2000-2020. The K-factor was derived and computed from the Harmonized World Soil Database (HWSD), a combination of regional and national soil information systems with the soil information of FAOUNESCO World Digital Soil Map (DSMW), [27]. Gridbased similar soil data was also obtained from design and inspection or ministry of water resource in Ethiopia for cross-validation. A $30 \times 30 \mathrm{~m}$ resolution SRTM DEM map was downloaded from USGS (https://earthexplorer.usgs.gov/) to compute the LS factor. Cover management factor was computed from Landsat 08 satellite imagery which was downloaded from USGS earth explorer and the support practice (P) factor was computed using the integration of land use and slope gradient parameters. Fig. 2 shows the map of all input parameters to conduct the present study.
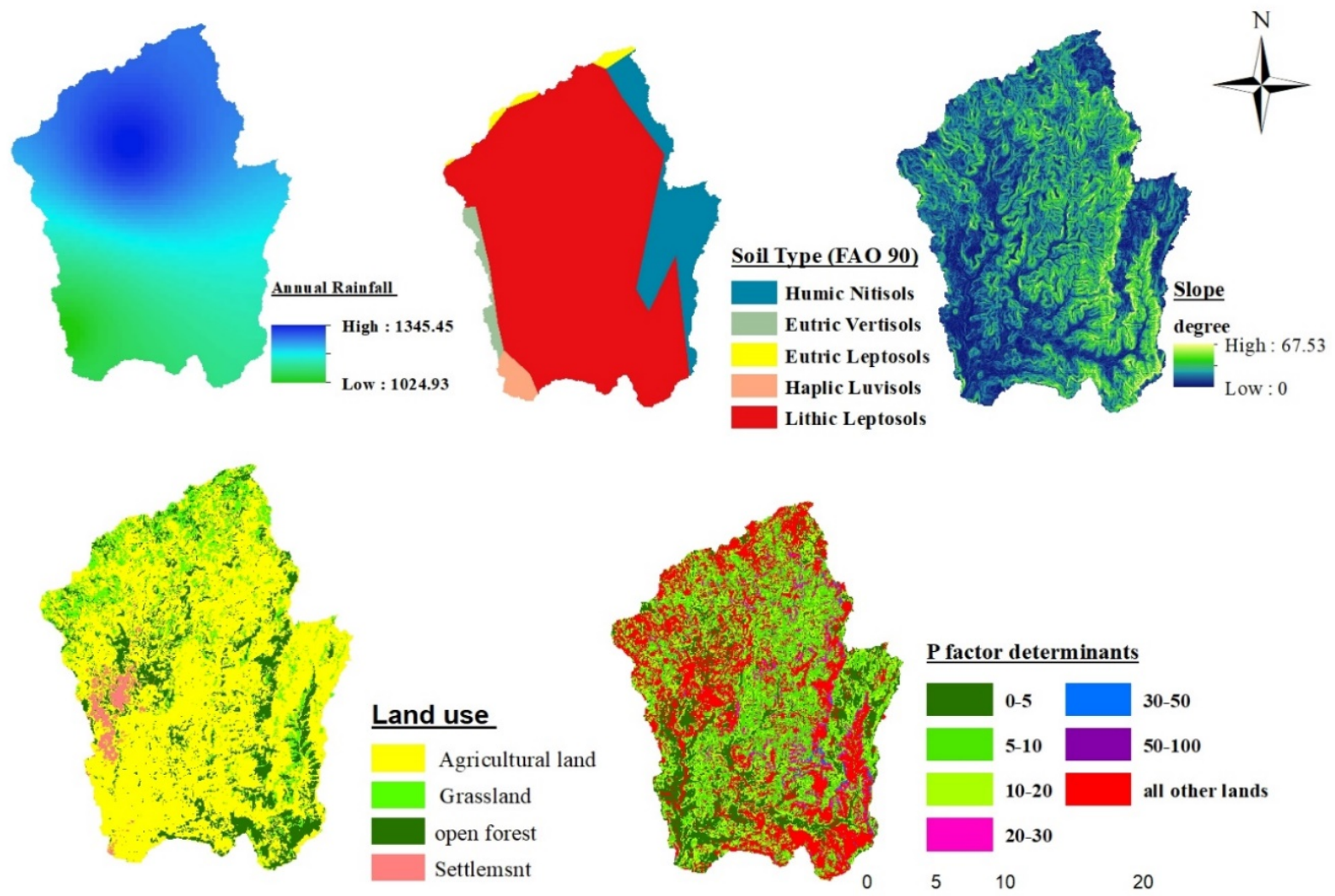

$\underline{\text { P factor determinants }}$

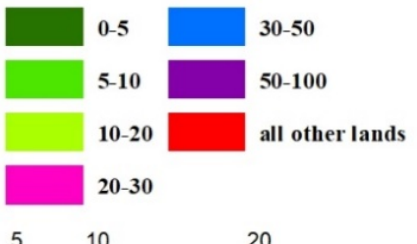

Fig. 2 The input factors for RUSLE model

\section{RUSLE model parameters}

The RUSLE model has been widely used, a non-datademanding and cheap predictive model for both forest and agricultural watersheds [28]. This model can be used usually institutional data, such as medium to low- resolution satellite images and finite rainfall data [29]. Besides, the RUSLE model output allows soil conservationists to determine the spatial pattern of soil loss [30]. This permits us to identify the critical areas within fields or catchments that are contributing major 
amounts of soil loss. The RUSLE was implemented for the annual soil erosion estimations and mapping by incorporating six factors; rainfall erosivity (R), soil erodibility $(\mathrm{K})$, slope-length $(\mathrm{L})$, slope-steepness $(\mathrm{S})$, cover management $(\mathrm{C})$, and conservation practice $(\mathrm{P})$ [31]. The mean annual soil loss in the Megech watershed was estimated based on the RUSLE general formula given in equation (1) [32]:

$$
A=R * K * L * S * C * P
$$

Where; $\mathrm{A}=$ estimated mean annual soil loss (ton ha-1 $\mathrm{yr}-1), \mathrm{R}=$ erosivity factor (MJ mm ha-1 h- $1 \mathrm{yr}-1), \mathrm{K}$ reflects soil erodibility factor ( $\mathrm{Mg} \mathrm{h} \mathrm{MJ-1} \mathrm{mm-1),} \mathrm{LS} \mathrm{=}$ slope length and gradient factors, $\mathrm{C}=$ cover factor and $\mathrm{P}$ $=$ erosion control practice factor.

$\mathrm{R}$ factor is the climatic factor that contributes to soil loss through detaching and transporting power by raindrop and runoff forces respectively [8]. Rainfall intensity and duration are the main significant factors of the $\mathrm{R}$ factor. Raindrop/splash erosion is the dominant type of erosion in barren soil surfaces that cause the soil to detach, separate the aggregated soil particles, and initiate them to transport downstream areas [33]. The $\mathrm{R}$ factor is computed by multiplying the maximum 30minutes intensity of rainfall and kinetic energy for individual rainfall events [32]. In an ungauged watershed, the $\mathrm{R}$ factor can be calculated using the average annual rainfall data of nearby weather stations [34]. For the present study, the R-factor was computed from the rainfall data collected from 14 in and nearby weather stations' starting from 2000 - 2020 which are monitored by the NMA of Ethiopia. R-factor was calculated using equation (2) which is developed by [32], for Ethiopia modified by [14] and utilized by [35]:

$R=-8.12+0.562 * \mathrm{P}$, at $\left(\mathrm{r}^{2}=1\right)$

Where, $\mathrm{R}=$ Rainfall erosivity $\left(\mathrm{MJ} \mathrm{mm} \mathrm{ha}^{-1} \mathrm{~h}^{-1} \mathrm{y}^{-1}\right)$ and $\mathrm{P}$ $=$ mean annual precipitation ( $\mathrm{mm} /$ year). The calculation was computed in the ArcGIS environment spatial analysis tool using the Inverse Distance Weight (IDW) power of two interpolation methods. The output layer map was then transformed to a 30 by $30 \mathrm{~m}$ raster grid.

Erodibility indicates the capability of the soil to withstand detaching, beating, and eroding forces. The $\mathrm{K}$ value designated to a particular soil type reflects the amount of soil lost per unit of erosive energy compared to bare soil, assuming a standard USLE research plot is
$22.1 \mathrm{~m}$ long by $1.83 \mathrm{~m}$ wide, and $9 \%$ slope [28], [32]. The percentage of topsoil sand, silt, clay, and organic carbon (OC) are the determinant factors to compute the $\mathrm{K}$ factor [32]. Although a detailed soil sample is needed, soil data was obtained from HWSD to compute the K factor. HWSD is compiled from four soil databases, the World Digital Soil Map (DSMW), the European Soil Database (ESDB), the 1:1 million soil map of China, and different regional and national SOTER databases [27]. HWSD consists of a 30 arc-second raster image linked with Microsoft access formatted attribute database that consisted of the determinant soil properties including; topsoil of sand, silt, clay, and OC which are the determinant factors to calculate the $\mathrm{K}$ factor. The $\mathrm{K}$ factor is then calculated based on equation (3) developed by [36].

$K=A * B * C * D * 0.1317$

Where each letter has its formula:

$$
\begin{aligned}
& A=[0.2+0.3 \exp (-0.0256 \operatorname{SAN}(1-(\text { SIL100) }))] \\
& B=\left[\frac{\text { SIL }}{\text { CLA }}\right]^{0.3} \\
& C=[1.0-(0.25 C+\exp [(3.72-2.95 C)])] \\
& D=[1.0-(0.70 S N 1 S N 1+\exp [(-5.41+ \\
& 22.9 S N 1)])]
\end{aligned}
$$

Where: SAN indicates percent sand; SIL indicates percent silt, CLA indicates percent clay; $\mathrm{C}$ indicates organic carbon (OC \%) content, and $\mathrm{SN} 1$ indicates sand percentage subtracted from one and divided by 100 . Using an ArcGIS format, the final computed $\mathrm{K}$ value was added on the attribute table of the masked watershed from the soil map and created a raster map by clicking the symbology option in properties and then converting it to a 30 by $30 \mathrm{~m}$ raster grid using attribute data of $\mathrm{K}$ value to develop a K-factor map.

The LS factor measures the effect of length and steepness of slope on soil erosion. L value is computed by dividing the actual horizontal slope length to the experimentally measured slope length of $22.1 \mathrm{~m}$, and the $\mathrm{S}$ factor is calculated as a ratio of the actual slope to an experimental slope (9\%) [28], [32], [33]. LS factor was computed from 3 arc-sec SRTM DEM with $30 \mathrm{~m}$ resolution which was downloaded from USGS earth explorer (https://earthexplorer.usgs.gov/). The DEM was extracted by the study watershed shapefile and subjected to raster calculation to obtain $\mathrm{L}$ and $\mathrm{S}$ factors. The computation of LS factors requires pre-processing of 
flow accumulation and slope angle. The DEM was used as an input to process flow accumulation and slope angle in ArcGIS Spatial analyst plus arc hydro tools extension. L factor was calculated based on the improved RUSLE equations described below using equation (4) [32]:

$L=\left(\frac{\lambda}{22.13}\right)^{\mathrm{m}}$

Where; L reflects slope length factor; $\lambda$ is horizontal field slope length in meter and " $\mathrm{m}$ " is the variable slope length exponent. In the original USLE, the " $\mathrm{m}$ " value for slope level greater than $5 \%$ is 0.5 , which is the same for all slopes greater than 5\%. However, RUSLE uses equations (4.1 and 4.2) to improve the value of the slope exponent [28]. Therefore, the slope exponent value increase as slope inclination gets higher. The value of $\beta$ is computed based on slope angle for soils sensitive to sheet and rill erosion [37], [38]. In this study, the extracted DEM of the Megech watershed was subjected to equations (4.1 and 4.2) and finally computed by equation (4) to compute the $\mathrm{L}$ factor.

$m=\frac{\beta}{(1+\beta)}$

$\beta=\frac{\left(\frac{\sin \theta}{\sin \theta}\right)}{\left.[\sin \theta]^{0.18}+0.56\right]}$

Where $\beta$ is the relative proportion of rill to inter-rill erosion and $\theta$ is slope gradient angle. The $\mathrm{S}$ factor was computed based on equations (5 and 6) as described in RUSLE handbook 703 [28], [38].

$S=10.8 \sin \theta+0.03$, for $\theta<9 \%$

$S=16.8 \sin \theta-0.50$, for $\theta \geq 9 \%$

Where $\mathrm{S}$ indicates slope gradient factor; and $\theta$ indicates slope angle. The topographic factor in the RUSLE model was then obtained by multiplying $\mathrm{L}$ and $\mathrm{S}$ factors.

$\mathrm{C}$ factor is the ratio of soil loss from particular cropland to the corresponding soil loss from clean-tilled, continuous fallow lands, and generally, the value ranges from 0.001 for dense forests to 1.0 for bare land [32], [33]. It explains the level of protection of soil under specified land cover management. Because of the variation of land cover with spatial and temporal patterns, Landsat 08 satellite imagery acquired on January 30, 2019, with 30×30 m resolution was downloaded from USGS earth explorer (https://earthexplorer.usgs.gov/) to compute the C factor. From the 11 bands, only 6 from (band 2-7) were selected and combined as a composite band in the ArcGIS environment. Because these bands have high resolution to visualize and classify the targeted land use type. By changing and selecting the appropriate band combinations, the appropriate LULC types were classified in the Megech watershed using a maximum likelihood supervised classification system. Ground reference points taken from google earth and manually surveyed ground control points were used for accuracy assessment. 160 control points were selected in simple random sampling methods to compute the accuracy assessment of the classified image. A confusion matrix was created in the ArcGIS environment using a pivot table toolbox under the data management tool. Overall accuracy was computed by dividing the total number of correctly classified pixels by the total number of sampled (references) pixels.

The support practices (P) factor is the relative proportion of soil loss with certain erosion control practices to the corresponding soil loss if the cultivation system is up and down the slope [32]. The P-value is 1 for soils without support practices and close to zero when proper erosion control barriers are implemented. Several support/ erosion control practices include contour strip-cropping, tillage on the contour, terrace systems, and grassed waterways, all of which acting as a barrier for runoff velocity at the same time reduce soil erosion and tend to reduce the $\mathrm{P}$ factor [39]. A detailed assessment of erosion protection measures is necessary to obtain an accurate result of the support practice factor. However, because of the availability of inconsistent data on different soil conservation measures in the study area, the combined effect of land use and slope gradient were used as input parameters to calculate and drive the $\mathrm{P}$ factor map (Table 1 \& Fig. 3).

Table $1 \mathrm{P}$ factor of Megech watershed based on [32]

\begin{tabular}{lll}
\hline Land Use & Slope (\%) & P value \\
\hline Agricultural Land & $0-5$ & 0.1 \\
& $5-15$ & 0.12 \\
& $15-30$ & 0.14 \\
& $30-50$ & 0.19 \\
& $50-75$ & 0.25 \\
& $>75$ & 0.33 \\
Other land uses & & 1 \\
\hline
\end{tabular}




\section{Soil loss estimation and severity mapping}

After computing and creating a 30x30 m raster layer for the six parameters, the final soil loss calculation was made by multiplying these parameters using the raster calculator under the spatial analysis tool of ArcGIS environment using equation (1). Finally, the erosion severity map was generated by sub-dividing the main watershed into 27 sub-watersheds. The 27 sub- watersheds were Delineated during the delineation of the main watershed using the SWAT model extension in ArcGIS. The main reason for using the SWAT model extension was that we can set a minimum area threshold level. The sub-watersheds were delineated using the initial area of 500 ha which is recommended for the objective of land development and soil conservation plan [40].

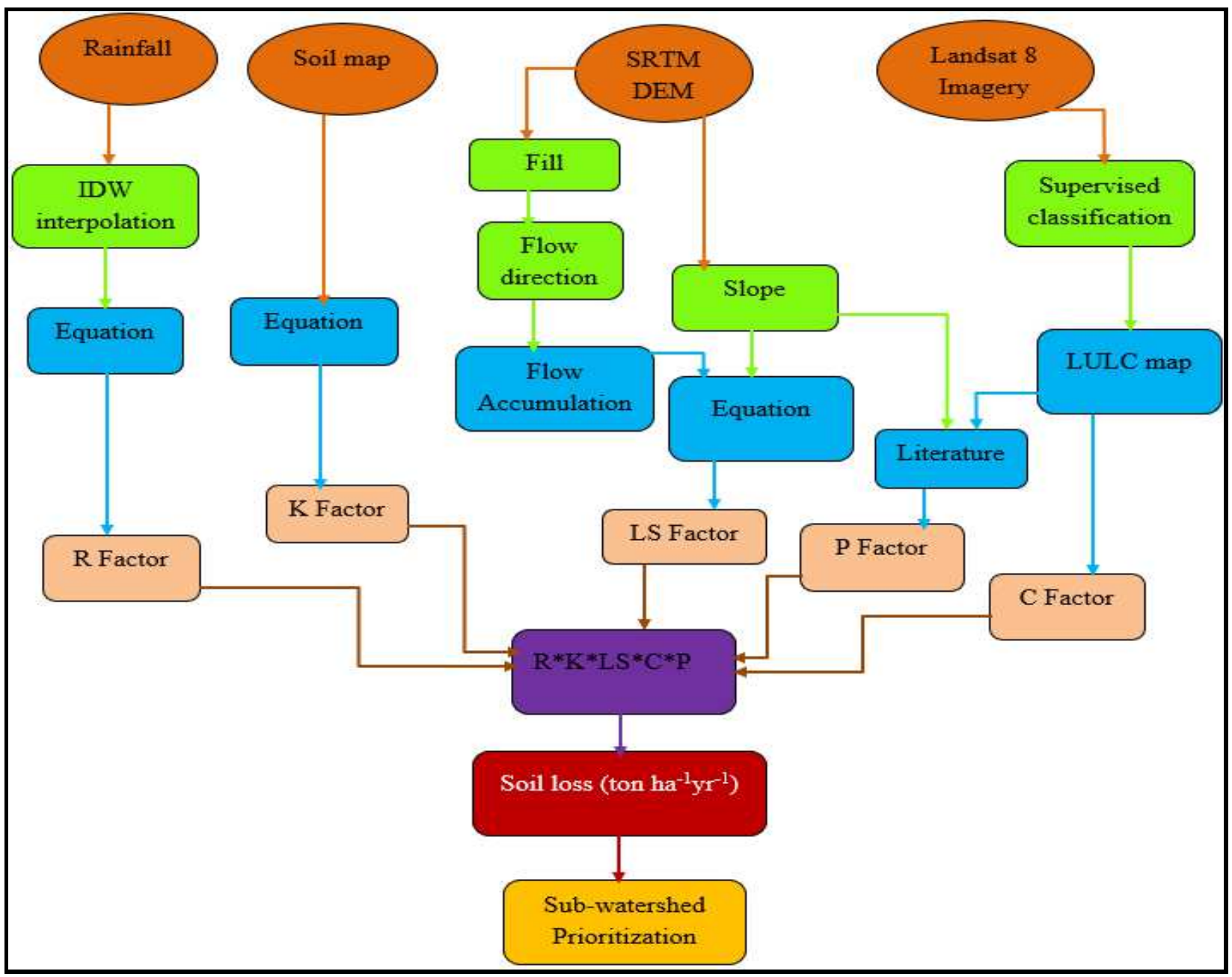

Fig. 3 The RUSLE model flowchart

\section{Results and Discussions}

The spatial soil erosion rate was assessed and quantified from a cell-by-cell raster calculation using the six RUSLE model parameter layers: rainfall erosivity, soil erodibility, topographic factors, cover management, and erosion control practice factors in ArcGIS software. The soil erosion severity map was also created which could be provided as a guide for farmers, developmental agents, and land managers for an appropriate conservation intervention plan.
Rainfall Erosivity (R): Rainfall intensity and duration are the main significant factors of this parameter. Annual rainfall distribution in the study watershed was ranged from 1024.93-1345.45 $\mathrm{mm}$. The computed $\mathrm{R}$ factor was ranged from 567.89 to $748.03 \mathrm{MJ} \mathrm{mm} \mathrm{ha} \mathrm{m}^{-1} \mathrm{~h}^{-1} \mathrm{yr}^{-1}$ with an average value of $672.5 \mathrm{MJ} \mathrm{mm} \mathrm{ha}{ }^{-1} \mathrm{~h}^{-1} \mathrm{yr}^{-1}$ (Fig. 4). Thus, this R-value has a great weight on total annual soil loss computation. The spatial distribution of the $\mathrm{R}$ factor was higher from the northern to the mid-part of the watershed. However, the $\mathrm{R}$ factor decreased when we 
moved from the northern to the southern (outlet) part of the watershed. Protection activities used to minimize the impact of rainfall, runoff and sedimentation can be adopted based on the erosivity values.

Soil Erodibility (K): Based on the extraction from HWSD, Megech watershed has about five soil types: Humic Nitisols, Eutric Vertisols, Eutric Leptosols, Haplic Luvisols, and Lithic Leptosols with its corresponding textural classes of heavy clay, light clay, loam, sandy clay loam, and clay loam of which Lithic Leptosols is the dominant soil type which accounts $80.6 \%$ of the total study area (Fig. $2 \& 4$ ). The $\mathrm{K}$ values for the study watershed were $0.1,0.14,0.21,0.26$, and $0.49 \mathrm{Mg} \mathrm{ha}^{-1} \mathrm{MJ}^{-1} \mathrm{~mm}^{-1}$ for Humic nitisols, Eutric vertisols, Eutric Leptosols, Haplic Luvisols, and Lethic Leptosols respectively (Table 2).
The $\mathrm{K}$ factor equation used in this study allows the variability of $\mathrm{K}$ values from 0.1 to 0.5 which is documented in the US Department of Agricultural Technical Bulletin No.1768. [36]. The K value normally varied from near zero to about 0.6 , and it is very low for soils with high water retaining capacities, such as welldrained sandy soils or friable tropical clays with high in hydrous oxides of iron and aluminum or kaolinite [1]. The $\mathrm{K}$ factor computed in this study was therefore realistic. Soil erodibility depends mainly on the content of OM in the soil and soil texture [41]. Generally, soils with high water infiltration capacities and moderate soil structural stability have a K-factor of 0.2 to 0.3 , while the most easily eroded soils with low infiltration capacities will have a K-factor of 0.3 or highest [1].

Table 2 Major soil types at Megech watershed and the corresponding $\mathrm{K}$ value

\begin{tabular}{lllll}
\hline Soil type (FAO 90) & Texture (USDA) & K Factor & Area (ha) & Area (\%) \\
\hline Eutric Leptosols (Lpe) & loam & 0.21 & 460.88 & 1.1 \\
Lithic Leptosols (LPq) & clay loam & 0.49 & 34423.88 & 80.6 \\
Haplic Luvisols (LVh) & Sandy clay loam & 0.26 & 776.7 & 1.8 \\
Humic Nitisols (NTu) & clay & 0.1 & 6244.55 & 14.6 \\
Eutric Vertisols (Vre & light clay & 0.14 & 800.52 & 1.9 \\
\hline Where K value is in $\mathrm{Mg} \mathrm{ha}^{-1} \mathrm{MJ}^{-1} \mathrm{~mm}$ & & &
\end{tabular}

Where $\mathrm{K}$ value is in $\mathrm{Mg} \mathrm{ha}^{-1} \mathrm{MJ}^{-1} \mathrm{~mm}$

Lithic Leptosols had the greatest (0.49) K-value while, Humic Nitisols which is found in the eastern part of the watershed, had the least (0.1) K-value. Lithic Leptosols followed by Haplic Luvisols are more sensitive to erosion. Whereas, Humic Netisols and Eutric Vertisols are less susceptible to rainfall-driven erosion. Soil with higher levels of OM is usually less sensitive to erosion because it coagulates soil colloids and creates a more stable and aggregated soil structure. Fine to medium textured soils and soils with low OM content have low infiltration capacity and, are more sensitive to water erosion [42], [43].

The topographic Factor: LS factor is the most significant factor of soil erosion for mountainous areas which is the characteristics of the Megech watershed. The average slope for the Megech watershed was $14^{\circ}$
(26.2\%) and it ranged from 0 to $68^{\circ}$ (Fig. 2), has higher topographic characteristics. More than $70 \%$ of the research area has a slope class of greater than strong to extremely strong $\left(>8^{\circ}\right)$, which means it aggravates rainfall-driven rill and inter-rill soil erosion. As described in Fig 5, soil loss in each slope class was increased as the slope class increased. About $32.8 \%$ of the watershed was categorized under the slope class of $8-16^{\circ}$ and had an average erosion rate of 18.6 tons ha ${ }^{1} \mathrm{yr}^{-1}$. The corresponding erosion values for slope classes of $0-3,3-5,5-8,16-24$, and greater than $24^{\circ}$ were 3.8 , $6.8,11.6,33.21$, and 73.6 tons $\mathrm{ha}^{-1} \mathrm{yr}^{-1}$ respectively. 


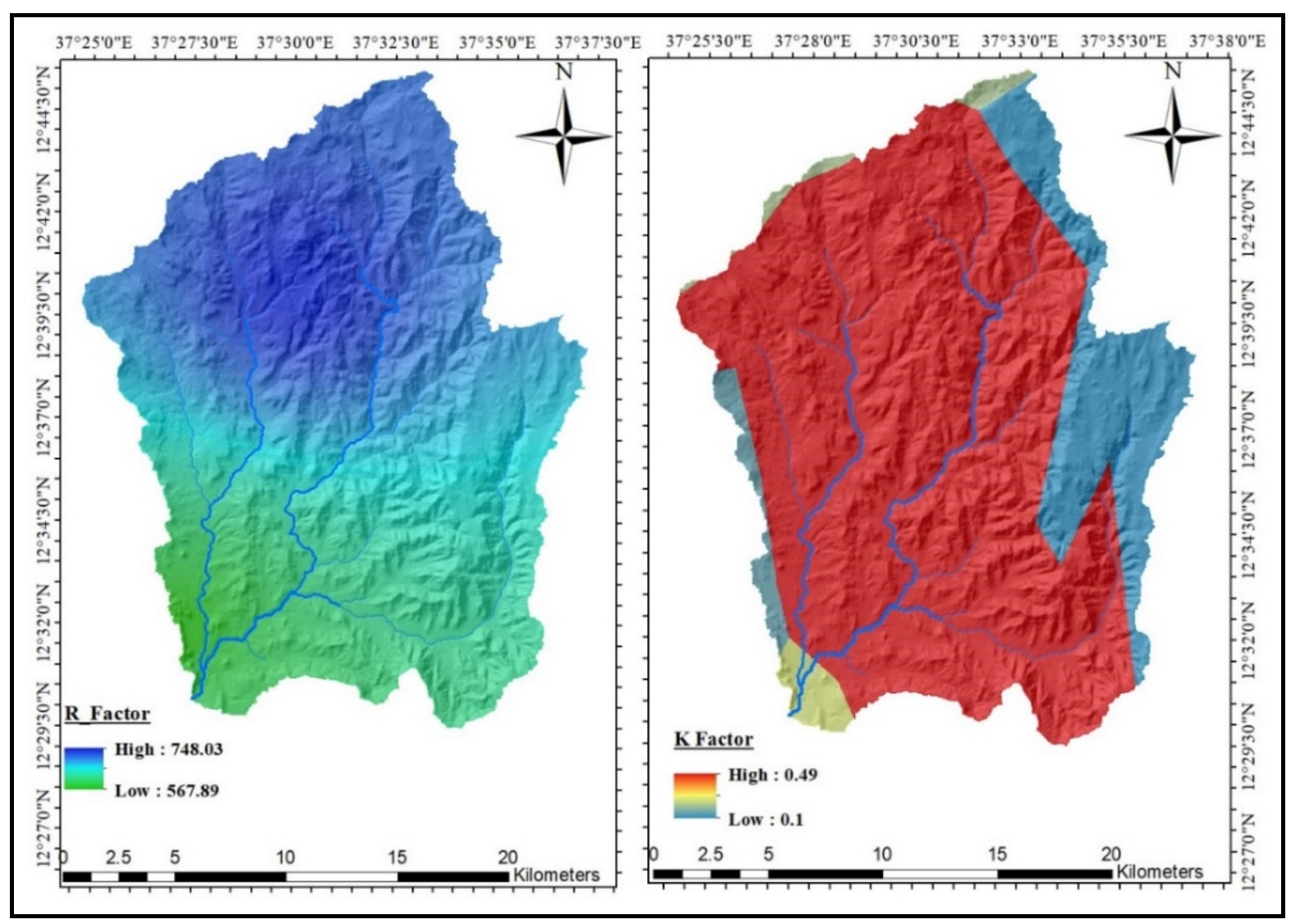

Fig. 4 Rainfall Erosivity and Soil Erodibility Map of Megech Watershed

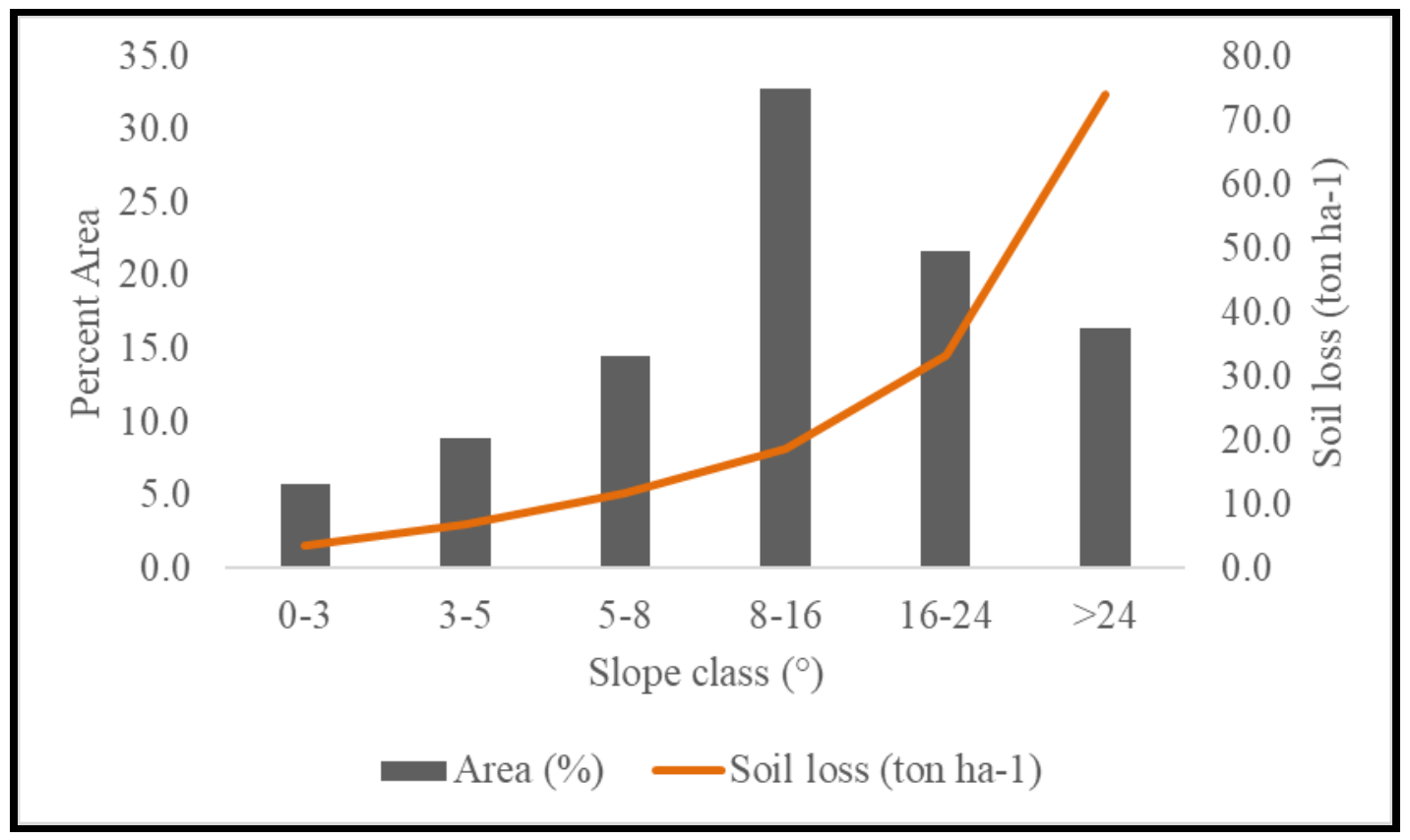

Fig. 5 The effect of slope gradient on soil loss

LS factor was calculated by using flow accumulation and slope angle using $30 \mathrm{~m}$ resolution DEM as an input parameter. The $\mathrm{L}$ factor was higher in valleys and depressions due to the high-flow accumulation rate (Fig. 6). Whereas, the $\mathrm{S}$ factor was higher in the southeastern to the central part of the watershed where the higher 
slope gradient was found (Fig. 6). The average LS factor value was 4.62 and generally, the LS factor ranged from 0.03 to 183.32 (Fig. 6). The average LS factor increases with increasing slope steepness and flow accumulation.
When slope length is higher, the opportunity for accumulation and concentration of runoff water is also higher; slope steepness also accelerates the runoff velocity [1], [32].

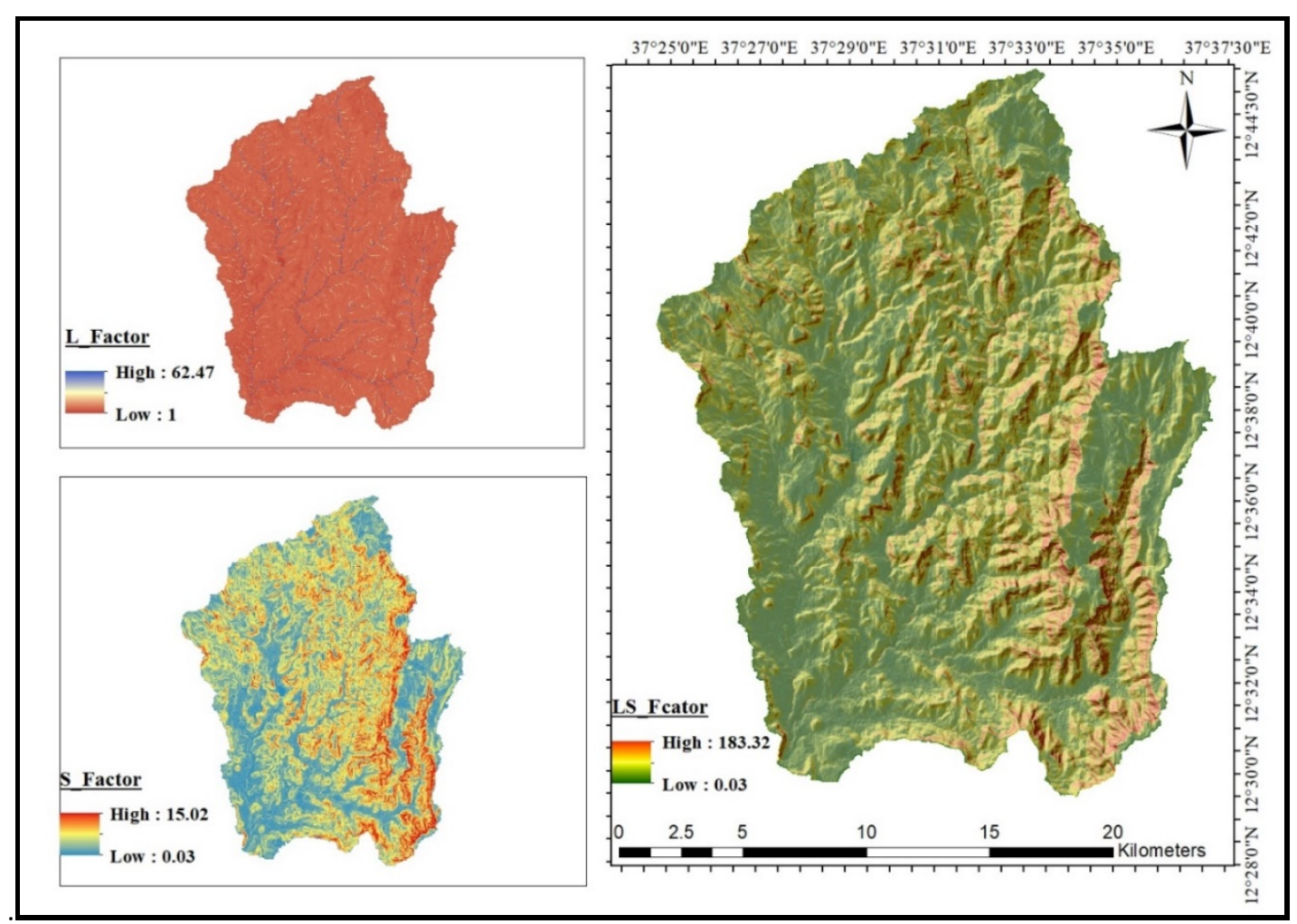

Fig. 6 LS Factor of Megech Watershed

Cover Factor (C): The major LULC types in the Megech watershed identified using supervised classification were open forest (16.31\%), grassland (11.4\%), agricultural land (70\%), and settlement (2.3\%). Based on the land use classes, the $\mathrm{C}$ factor values were assigned to each land use type and the $\mathrm{C}$ factor map was generated (Fig. 2 \& 7). The corresponding $\mathrm{C}$ factor values for these land-use types were $0.014,0.02,0.05$, and 0.15 for vegetation cover, settlement, grassland, and agricultural land respectively. This $\mathrm{C}$ factor classification was based on Hurni's and Hellden's classification of which for well-protected land assigned as 0 and for bare land it assigned as 1 [14], [35]. Nearsurface features such as well-grassed slopes, stem leaves, litter, and biological soil crusts have a greater contribution to reducing detachment, overland flow as well as soil erosion rate [44] As LULC type varies so does the $\mathrm{C}$ factor. Because the $\mathrm{C}$ factor is computed after the determination of the LULC type of specified area. Accuracy assessment provides the means to assess the confidence with which the classified image was accurate or not. The overall accuracy assessment of classified images in this study was $94.2 \%$ which is greater than the acceptable level. The acceptable level of overall accuracy assessment is taken as $85 \%$ [45].

Because of the suitability of the area for human settlement, vegetation removal for the expansion of cultivated lands is the common practice experienced in the northern highlands. Removing vegetation cover and intensive agricultural practices aggravates soil erosion, washing away the fertile top-soils that contain essential nutrients; leaving infertile and shallow soils with poor water retention capacity [17], [20]. Croplands are more sensitive to erosion as it is frequently tilled and vegetations are removed before planting the crop and the land is bare between two planting seasons [43]. Hence $70 \%$ of the area is occupied by agricultural land, the soil is intensively cultivated and manipulated; the watershed could be affected by rill and inter-rill erosion. 


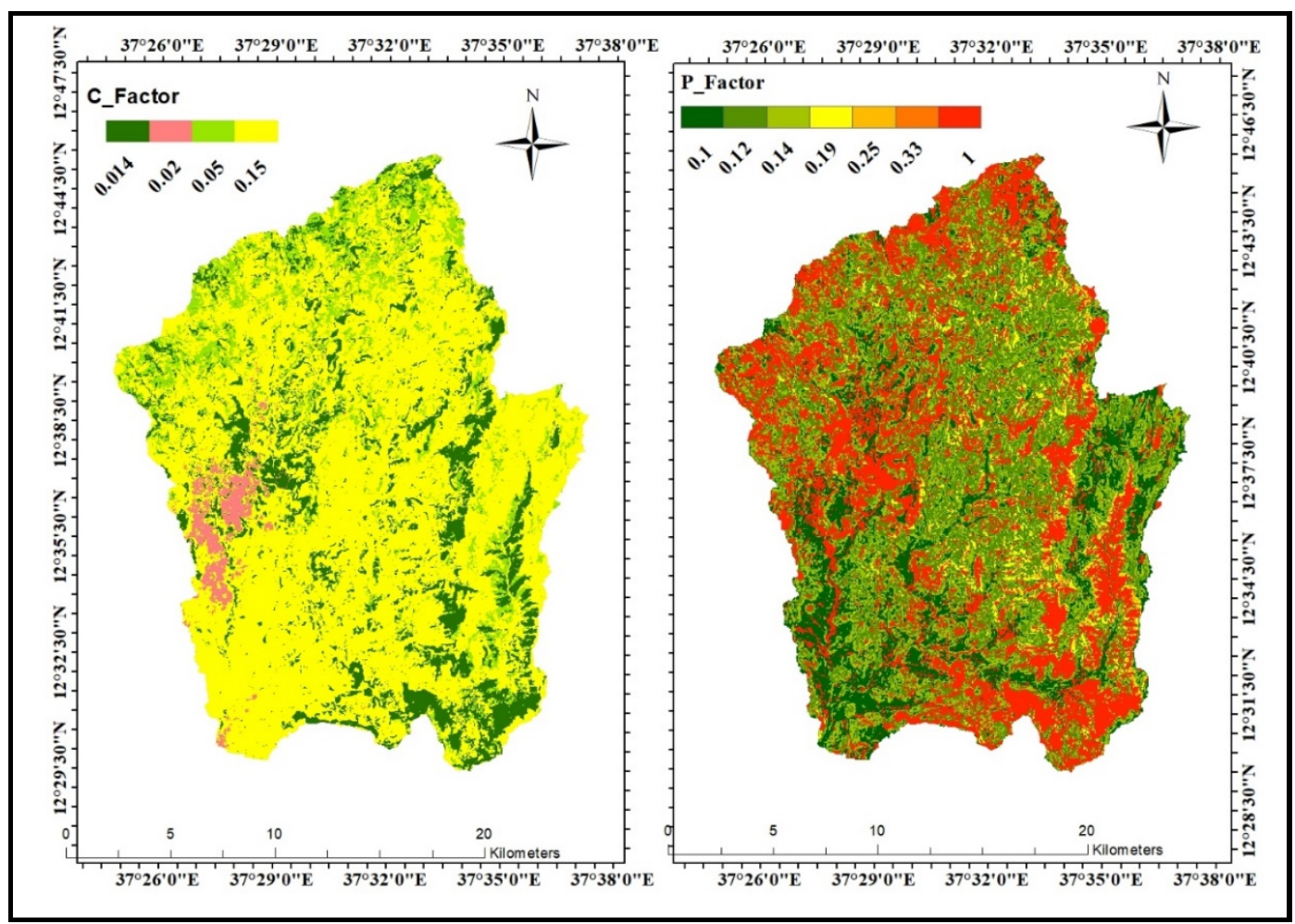

Fig. 7 C Factor and P Factor Map for Megech Watershed

Control Practices Factor (P): This factor measures the effect of erosion control measures on the surface runoff velocity and its corresponding impact on the total soil erosion rate [32]. A detailed study is necessary to obtain an accurate result of the support practice factor. However, because of the unavailability of full data on different conservation measures in the study area, the combined effect of land use and slope gradient were used as input parameters to calculate and drive the $\mathrm{P}$ factor map. Based on the RUSLE analysis, the P factor for agricultural lands ranges from 0.1 to 0.33 , while other land uses were assigned as the P-value of 1 as described in Fig. 7 and Table 1.

\section{Soil Loss Estimation and Severity Mapping}

The estimated total soil loss from the whole watershed was about $1,399,210$ tons $\mathrm{yr}^{-1}$ with a mean soil erosion rate of 32.84 tons $\mathrm{ha}^{-1} \mathrm{yr}^{-1}$. This finding is much higher than the country's soil loss threshold (5-12 tons $\mathrm{ha}^{-1} \mathrm{yr}^{-1}$ ) level [20]. The soil loss rate ranged from 0.03 tons $\mathrm{ha}^{-}$ ${ }^{1} \mathrm{yr}^{-1}$ in the eastern, outlet, and very flat lands to more than 500 tons $\mathrm{ha}^{-1} \mathrm{yr}^{-1}$ in the gorged, valley, and steep slope lands of the watershed (Fig. 8). The northwestern, mid-part, and southeastern part of the watershed was highly affected by soil erosion rate. This could be happened due to the larger area of cultivated land and the slope steepness factor experienced in the watershed in addition to other unexplained variables (Fig. 5 \& 8 ). Although there are many parameters, the topography is the major influencing factor that determines spatial soil erosion rate [46], [47]. Flow depth decreases and runoff velocity increased as slope gradient gets higher [48] The largest part of the watershed is dominated by the clay loam soil textural class that can be easily eroded by sheet/inter-rill erosion. Research conducted in China found that clay loam soil textural class has been highly affected by sheet/inter-rill erosion [49]. Intensive rainfall also scored in the northern part of the watershed, which could be the cause of severe erosion in the same area.

Uniform soil loss and severity could not be accrued in the watershed. This is because of the variation of input parameters such as land use, topography, soil type, and different soil and water management activities [50]. Creating an erosion severity map is important to decide on which area is highly affected by erosion so that it needs immediate action. This can be important to identify critical erosion hotspots and make prioritization between sub-watersheds to allocate limited resources for any erosion control measures and install suitable protection measures at the appropriate place [51], [52]. 
It can also be important in human and financial resources management [53].

Seven severity classes were used according to Morgan classification as 0-2, 2-5, 5-10, 10-50, 50-100, 100-500, and greater than 500 for very slight, slight, moderate, high, severe, very severe and catastrophic respectively [8]. Based on Morgan's classification, most of the subwatersheds are categorized under the high (10-50 tons $\mathrm{ha}^{-1} \mathrm{yr}^{-1}$ ) class (Fig. 8A), which is not a suitable erosion category to proceed to the second objective. Therefore, the severity class was modified based on the characteristics of the watershed and depending on the soil loss rate in each sub-watershed. The modified severity classes were low (0-10), moderate (10-20), high (20-30), very high (30-35), severe (35-40), very severe (40-45), and extremely severe (above 45) in which the values in brackets are mean annual soil loss in tons ha ${ }^{1} \mathrm{yr}^{-1}$.

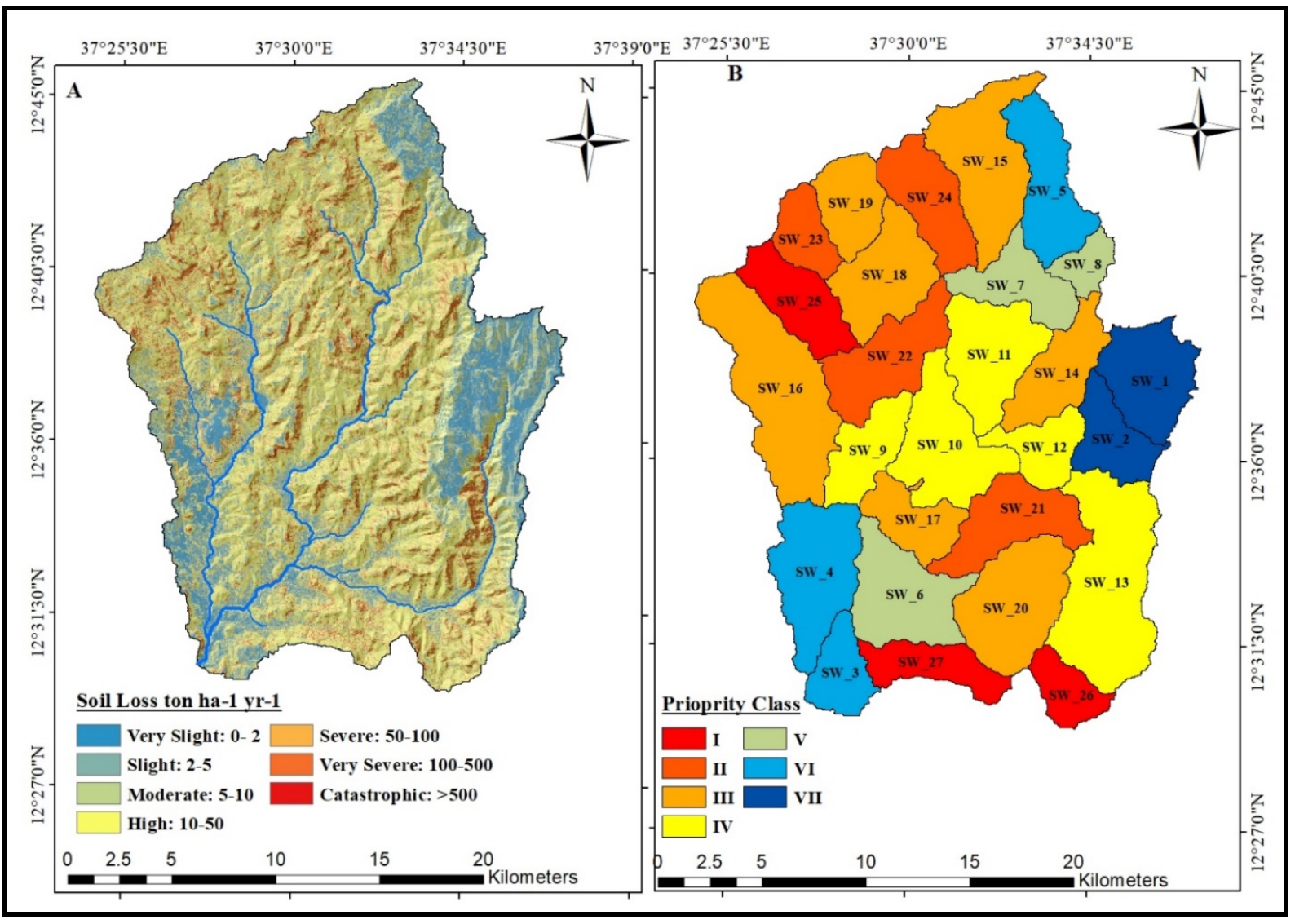

Fig. 8 Annual soil loss and severity class map of Megech watershed

The seven severity classes ranging from low erosion (VII) to extremely severe erosion class (I) was created to generate the severity map for the 27 sub-watersheds (Fig. 8 and Table 3). The corresponding area coverages starting from low erosion risk to extremely severe erosion risks were 2794, 4721, 3702, 9405, 13181, 5732, and 3171 ha respectively. Five sub-watersheds (SW_9 to SW_13) were ranked as a very high class (IV), Seven sub-watersheds (SW_14 to SW_20) were classified as severe (III), four sub-watersheds (SW_21 to SW_24) were categorized as very severe (II) class and finally, three sub-watersheds (SW_25 to SW_27) classified as extremely severe (I) class (Table 3). The sub-watersheds with extremely severe erosion have been given as $1^{\text {st }}$ priority class for a conservation plan and so on. About $82 \%$ of the Megech watershed was found more than the high-risk category which means it needs immediate conservation action based on the rank of the watersheds starting from the first ranked (extremely severe) subwatershed to the other consecutive sub-watersheds. It does not mean that the lower-ranked sub-watersheds do not need any conservation measure. However, the conservation measures should be considered after the completion of the top-ranked severe sub-watersheds. 
Table 3 Severity class of sub-watersheds for conservation prioritizations

\begin{tabular}{|c|c|c|c|c|c|c|}
\hline Watershed & $\begin{array}{l}\text { Area } \\
\text { (ha) }\end{array}$ & $\begin{array}{c}\text { Soil loss per } \\
\text { watershed (tons) }\end{array}$ & $\begin{array}{c}\text { Soil loss (ton } \\
\text { ha-1) }\end{array}$ & $\begin{array}{l}\text { Priority } \\
\text { Class }\end{array}$ & Severity & $\begin{array}{c}\text { Area coverage } \\
\text { based on Severity } \\
\text { (ha) }\end{array}$ \\
\hline SW_1 & 1697 & 4481.14 & 2.64 & VII & Low & 2794 \\
\hline SW_2 & 1097 & 7708.82 & 7.03 & & & \\
\hline SW_3 & 913 & 12249.51 & 13.42 & VI & Moderate & 4721 \\
\hline $\mathrm{SW}^{-} 4$ & 2127 & 31223.92 & 14.68 & & & \\
\hline SW_5 & 1681 & 30323.98 & 18.04 & & & \\
\hline SW_6 & 1960 & 43863.23 & 22.38 & $\mathrm{~V}$ & High & 3702 \\
\hline SW_7 & 1240 & 33931.96 & 27.37 & & & \\
\hline SW_8 & 503 & 13770.05 & 27.39 & & & \\
\hline SW_9 & 1139 & 35481.10 & 31.15 & IV & Very high & 9405 \\
\hline SW_-10 & 2080 & 66731.85 & 32.08 & & & \\
\hline SW_11 & 1869 & 63581.34 & 34.02 & & & \\
\hline SW-12 & 920 & 31981.82 & 34.75 & & & \\
\hline SW_13 & 3396 & 118189.15 & 34.8 & & & \\
\hline SW_14 & 1385 & 49627.18 & 35.82 & III & Severe & 13181 \\
\hline SW_15 & 2326 & 88316.70 & 37.97 & & & \\
\hline SW_16 & 3355 & 128017.26 & 38.16 & & & \\
\hline SW_17 & 1057 & 40929.20 & 38.74 & & & \\
\hline SW_18 & 1732 & 67321.11 & 38.88 & & & \\
\hline SW_19 & 1107 & 43044.23 & 38.89 & & & \\
\hline SW_20 & 2220 & 86687.54 & 39.04 & & & \\
\hline SW_21 & 1658 & 67772.68 & 40.87 & II & Very & 5732 \\
\hline SW_22 & 1765 & 77708.55 & 44.03 & & Severe & \\
\hline SW_23 & 808 & 36013.39 & 44.56 & & & \\
\hline SW_24 & 1501 & 67015.46 & 44.66 & & & \\
\hline SW_25 & 1355 & 64635.41 & 47.7 & $\mathrm{I}$ & Extremely & 3171 \\
\hline SW_26 & 753 & 36704.58 & 48.76 & & Severe & \\
\hline SW_27 & 1064 & 51900.26 & 48.8 & & & \\
\hline
\end{tabular}

\section{Validation}

Because of the difficulty of getting data for validation, previous research findings were used as a confirmation for the present study. The result found in this study was realistic as it was confirmed by previous research studies mentioned below: 30.6 tons $\mathrm{ha}^{-1} \mathrm{yr}^{-1}$ in using the RUSLE model [54]. The soil loss result of the current study was found in the range of the region's soil loss result which is about 16-50 tons $\mathrm{ha}^{-1} \mathrm{yr}^{-1}$ [55]. Another report also found about 27.5 tons $\mathrm{ha}^{-1} \mathrm{yr}^{-1}$ in the Abay River basin using RUSLE model [56], 10-35 tons $\mathrm{ha}^{-1} \mathrm{yr}^{-1}$ in Koga catchment using AnnAGNPS model [57], 37.5 tons ha ${ }^{1} \mathrm{y}^{-1}$ in Beshillo catchment in Blue Nile River basin using RUSLE model [58], 23.4 tons $\mathrm{ha}^{-1} \mathrm{y}^{-1}$ in central Ethiopia using RUSLE model [59] and 21.08 tons $\mathrm{ha}^{-1}$ in neighboring Gumara-Maksegnit watershed using SWAT model [60]. A basin-scale study in the Lake Tana subbasin using the SWAT model showed that the Megech watershed was found from the number one erosionsensitive sub-basins which accounted for an average annual sedimentation rate of 30-65 tons $\mathrm{ha}^{-1} \mathrm{yr}^{-1}$ [21].
The result found in the current study was in between the above-mentioned previous findings, which indicates that the finding was realistic.

\section{Conclusion}

A quantitative soil erosion assessment in the Megech watershed using the RUSLE model in a GIS interface had been conducted to quantify the mean annual soil loss and to identify erosion hotspots in the watershed. The RUSLE model estimated the mean annual erosion of the watershed as about 32.84 tons ha $^{-1} \mathrm{yr}^{-1}$ and total soil loss from the watershed was about 1,399,210 tons $\mathrm{yr}^{-1}$.

A specific severity map was also created for the subwatersheds as low erosion severity $\left(<10\right.$ tons $\left.\mathrm{ha}^{-1} \mathrm{yr}^{-1}\right)$, moderate erosion (10-20 tons ha-1), high erosion category (20-30 tons $\left.\mathrm{ha}^{-1} \mathrm{yr}^{-1}\right)$, very high (30-35 tons ha${ }^{1} \mathrm{yr}^{-1}$ ), severe (35-40 tons $\left.\mathrm{ha}^{-1} \mathrm{yr}^{-1}\right)$, very severe soil erosion (40-45 tons $\mathrm{ha}^{-1} \mathrm{yr}^{-1}$ ) and extremely severe (greater than 45 tons $\mathrm{ha}^{-1} \mathrm{yr}^{-1}$ ). Based on this classification system, about 2794 ha considered as low erosion, 4721 ha in the category of moderate erosion, 3702 ha in the category of high erosion on five sub- 
watersheds, 9405 ha in the category of very high erosion on eight sub-watersheds, 13181 ha on the category of severe erosion, 5732 ha under very severe erosion class and 3171 ha falls under extremely severe soil erosion category. About $82 \%$ of the area was found in more than high-risk categories which means it needs an immediate implementation of SWC measures based on the priority class of each sub-watershed. Thus, the Megech watershed especially the northwestern, midpart, and southeastern parts of the watershed required intensive protection measures. This is very important to save Lake Tana and Megech and Angereb reservoirs from sedimentation.

The severity map along with individual subwatersheds could be used to introduce targeted conservation practices and investments to address soil erosion problems across the entire watershed. Knowing the spatial pattern of erosion severity in different subwatersheds could be helped to target resources and monitor the progress at the sub-watershed scale with soil loss estimates for comprehensive and sustainable management of the watershed. This study also bears witness to that the RUSLE model integrated with the ArcGIS environment is a relevant and practical technique to check out spatial variability of soil erosion for appropriate soil and water management intervention. Further detailed research is needed to estimate the observed sediment load in the Megech dam reservoir. It can also be important to predict future soil erosion trends for a better pre-mitigation option.

\section{Abbreviations}

BNRB: Blue Nile River Basin; DEM: Digital Elevation Model; DSMW: Digital Soil Map of the World; GIS: Geographical Information System; HWSD: Harmonized World Soil Database; LULC: Land Use Land Cover; SRTM:Shuttle Radar Topography Mission; USGS: United States Geological Survey; RUSLE: Revised Universal Soil Loss Equation; SWAT: Soil and Water Assessment Tool.

\section{Authors' contributions}

Legese Abebaw: development of the methodology, collected, analyzed, interpreted the data and wrote the paper. Attila Nagy and Hailu Kendie: supervision and review and editing the paper. All authors read and approved the final manuscript.

\section{Acknowledgements}

The Authors would like to thank the staff of Gondar Agricultural research Center, Soil and Water Management Research Directorate for their frequent support and creating a good working environemt. We also acknowledge Mr. Atikilt Abera and Mr. Gashaw Gismu for providing us some essential data.

\section{Funding}

Not applicable.

Availability of data and materials Not applicable.
Ethics approval and consent to participate

Not applicable.

\section{Consent for publication}

Not applicable.

\section{Competing interests}

The authors declare that they have no competing interests.

\section{Author details}

${ }^{1}$ Amhara Regional Agricultural Research Institute, Gondar Agricultural Research Center, P.O. Box: 1337, Gondar, Ethiopia

${ }^{2}$ Amhara Regional Agricultural Research Institute, Bahir Dar, Ethiopia

${ }^{3}$ Faculty of Agricultural and Food Science and Environmental Management, University of Debrecen, Debrecen, Hungary

\section{References}

[1] N. C. Brady and R. R. Weil, The Nature and Properties of Soils, 15th ed., no. 1. The United States, 2003. doi: 10.16309/j.cnki.issn.1007-1776.2003.03.004.

[2] K. Hurni et al., "The Economics of Land Degradation. Ethiopia Case Study. Soil Degradation and Sustainable Land Management in the Rainfed Agricultural Areas of Ethiopia: An Assessment of the Economic Implications," Report for the Economics of Land Degradation Initiative, $\mathrm{p}$. 94, 2015.

[3] S. Arekhi and G. Rostamizad, "Sediment yield estimating from three micro-watersheds by integrated KW-GIUH and MUSLE models," Advances in Environmental Biology, vol. 5, no. 6, pp. 1346-1358, 2011.

[4] IPBES, "Summary for policymakers of the thematic assessment of land degradation and restoration," p. 32, 2018.

[5] D. Pimentel et al., "Land Degradation: Effects on Food and Energy Resources Linked references are available on JSTOR for this article: Land Degradation: Effects on Food and Energy Resources," Global Environmental Change, vol. 8, no. 2, pp. 149-155, 1976.

[6] L. R. Oldeman, R. Hakkeling, and W. Sombroek, "World map of the status of soil degradation, an explanatory note," 1990.

[7] J. R. Comino et al., "Rainfall and human activity impacts on soil losses and rill erosion in vineyards (Ruwer Valley, Germany)," Solid Earth, vol. 6, no. 3, 2015, doi: 10.5194/se-6-823-2015.

[8] R. P. C. Morgan, Soil Erosion and Conservation, 3rd ed. USA, UK, and Australia: Blackwell Publishing company, 2005.

[9] D. Pimentel et al., "Environmental and economic costs of soil erosion and conservation benefits," Science, vol. 267, no. 5201, pp. 1117-1123, 1995, doi: 10.1126/science.267.5201.1117.

[10] K. Menale, J. Pender, M. Yesuf, G. Kohlin, R. Bluffstone, and E. Mulugeta, "Impact of Soil Conservation on Crop Production in the Northern Ethiopian Highlands," IFPRI Discussion Paper, no. December, p. 44, 2007.

[11] FAO, Global soil status, processes and trends. 2015.

[12] H. K. Addis and A. Klik, "Predicting the spatial distribution of soil erodibility factor using USLE nomograph in an agricultural watershed, Ethiopia," International Soil and Water Conservation Research, vol. 3, no. 4, pp. 282-290, Dec. 2015, doi: 10.1016/j.iswcr.2015.11.002.

[13] FAO, "Ethiopian Highlands Reclamation Study, Final Report.," Food and Agriculture Organization of the United Nations, Rome, vol. Volume 1, 1986.

[14] H. Hurni, "Conservation Systems in Ethiopia," Pla Sentis, 1. (Edt.), vol. 674, pp. 1-20, 1985.

[15] H. Hurni, "Land degradation, famine, and land resource scenarios in Ethiopia," in World Soil Erosion and Conservation, 1993, pp. 27-61.

[16] A. A. Taye, Caring for the land: best practices in soil and water conservation in Beressa watershed, highlands of Ethiopia. 2006. 
[17] H. Hurni et al., "Land Degradation and Sustainable Land Management in the Highlands of Ethiopia," Global Change and Sustainable Development: A Synthesis of Regional Experiences from Research Partnerships., vol. Vol. 5. Be, pp. 187-207, 2010.

[18] A. Birhanu, "Environmental Degradation and Management in Ethiopian Highlands: Review of Lessons Learned," International Journal of Environmental Protection and Policy, vol. 2, no. 1, pp. 24-34, 2014, doi: 10.11648/j.ijepp.20140201.14.

[19] A. Halefom, E. Sisay, T. Worku, D. Khare, M. Dananto, and K. Narayanan, "Precipitation and Runoff Modelling in Megech Watershed, Tana Basin, Amhara Region of Ethiopia," American Journal of Environmental Engineering, vol. 8 , no. 3, pp. 45-53, 2018, doi:

10.5923/j.ajee.20180803.01.

[20] H. Hurni, "Degradation and Conservation of the Resources in the Ethiopian Highlands," Mountain Research and Development, vol. 8, no. 2, pp. 123-130, 1988

[21] S. G. Setegn, S. Ragahavan, D. Bijan, and A. M. Melesse, "Spatial delineation of soil erosion vulnerability in the Lake Tana Basin, Ethiopia," HYDROLOGICAL PROCESSES, vol. 23, pp. 3738-3750, 2009, doi: 10.1002/hyp.

[22] N. Efthimiou, E. Lykoudi, and C. Karavitis, "Soil erosion assessment using the RUSLE model and GIS," European Water, vol. 47, pp. 15-30, 2014.

[23] H. Lemma, A. Frankl, A. van Griensven, J. Poesen, E. Adgo, and J. Nyssen, "Identifying erosion hotspots in Lake Tana Basin from a multisite Soil and Water Assessment Tool validation: Opportunity for land managers," Land Degradation and Development, vol. 30, no. 12, pp. 1449 1467, 2019, doi: 10.1002/ldr.3332.

[24] H. Hurni, "Agroecological belts of Ethiopia: Explanatory notes on three maps at a scale of 1:1,000,000," Research Report, Soil conservation research program, Addis Ababa, p. 43, 1998.

[25] D. Conway, "A water balance model of the Upper Blue Nile in Ethiopia," Hydrological Sciences Journal, vol. 42, no. 2, pp. 265-286, 1997, doi: 10.1080/02626669709492024.

[26] WWDSE, "Feasibility Study and Detailed design of Irrigation and Drainage project in Lake Tana Sub-Basin Megech project report, Water Works Design \& Supervision Enterprise.," Addis Ababa, Ethiopia, 2008.

[27] FAO/IIASA/ISRIC/ISS-CAS/JRC, Harmonized World Soil Database (version 1.2), no. 1. FAO, Rome, Italy and IIASA, Laxenburg, Austria, 2012. doi: 10.16309/j.cnki.issn.10071776.2003.03.004

[28] K. G. Renard, G. R. Foster, G. A. Weesies, D. K. McCool, and D. C. (Coordinators). Yoder, Predicting Soil Erosion by Water: A Guide to Conservation Planning With the Revised Universal Soil Loss Equation (RUSLE). Agriculture Handbook 703, US Govt. Printing Office, in press. 1997.

[29] V. Prasannakumar, H. Vijith, S. Abinod, and N. Geetha, "Estimation of soil erosion risk within a small mountainous sub-watershed in Kerala, India, using Revised Universal Soil Loss Equation (RUSLE) and geo-information technology," Geoscience Frontiers, vol. 3, no. 2, pp. 209 215, 2012, doi: 10.1016/j.gsf.2011.11.003.

[30] M. R. A. Sardari, O. Bazrafshan, T. Panagopoulos, and E. R. Sardooi, "Modeling the impact of climate change and land-use change scenarios on soil erosion at the minab dam watershed," Sustainability (Switzerland), vol. 11, no. 12, 2019, doi: 10.3390/su10023353.

[31] U. Kabir, A. M. Mir, and M. Sajana, "Assessment of land cover change and its impact on changes in soil erosion risk in Nepal," Sustainability (Switzerland), vol. 10, no. 12, 2018, doi: $10.3390 /$ su10124715.

[32] W. H. Wischmeier and D. D. Smith, Predicting rainfall erosion losses: a guide to conservation planning Beltsville, Maryland. U.S. Department of Agriculture, Agriculture Handbook No. 537. Washington DC, 1978.

[33] S. Arekhi, "Evaluating long-term annual sediment yield estimating the potential of GIS interfaced MUSLE model on two micro watersheds," Pakistan Journal Biological science, pp. 270-274, 2008, doi: 10.3923/pjbs.2008.270.274

[34] G. Renard and R. Freimund, "Using monthly precipitation data to estimate the R-factor in the revised USLE," Journal of Hydrology, vol. 157, no. 1-4, pp. 287-306, 1994, doi: 10.1016/0022-1694(94)90110-4.

[35] Hellden, "An Assessment of Woody Biomass, Community Forests, Land-use, and Soil Erosion in Ethiopia," LUND UNIVERSITY PRESS, no. 14, 1987.

[36] A. N. Sharpley and J. R. Williams, "EPIC - Erosion / Productivity Impact Calculator," The US, 1768, 1990. G. R. Foster, L. D. Meyer, and C. A. Onstad, "Runoff Erosivity Factor and Variable Slope Length Exponents for Soil Loss Estimates.," Transactions of the American Society of Agricultural Engineers, vol. 20, no. 4, pp. 683687, 1977, doi: 10.13031/2013.35628.

[38] D. K. McCool, L. C. Brown, G. R. Foster, C. K. Mutchler, and L. D. Meyer, "Revised Slope Steepness Factor for the Universal Soil Loss Equation.," Transactions of the American Society of Agricultural Engineers, vol. 30, no. 5, pp. 1387-1396, 1987, doi: 10.13031/2013.30576.

[39] S. Arekhi, A. Shabani, and G. Rostamizad, "Application of the modified universal soil loss equation (MUSLE) in the prediction of sediment yield (Case study: Kengir Watershed, Iran)," Arabian Journal of Geosciences, vol. 5 , no. 6 , pp. 1259-1267, 2010, doi: 10.1007/s12517-0100271-6.

[40] L. Desta, C. Volli, W.-A. Asrat, and A. Yiteyew, Community-Based Participatory Watershed Development: A Guideline. Federal Democratic Republic of Ethiopia Ministry of Agriculture and Rural Development, Addis Ababa, Ethiopia. 2005

[41] R. P. Stone and D. Hilborn, "Universal soil loss equation, USLE: Ministry of Agriculture, Food and Rural Affairs," no. 00, pp. 1-8, 2000.

[42] R. Lal and B. A. Stewart, Volume 11: Soil Degradation. 1990.

[43] D. Pimentel, "Soil erosion: A food and environmental threat," Environment, Development, and Sustainability, vol. 8, no. 1, pp. 119-137, 2006, doi: 10.1007/s10668-0051262-8.

[44] Q. Ma, K. Zhang, Z. Cao, Z. Yang, M. Wei, and Z. Gu, "Impacts of different surface features on soil detachment in the subtropical region," International Soil and Water Conservation Research, vol. 9, no. 4, 2021, doi: 10.1016/j.iswcr.2021.04.001.

[45] J. R. Anderson, E. E. Hardy, J. T. Roach, and R. E. Witmer, "LAND USE AND LAND COVER CLASSIFICATION SYSTEM FOR USE WITH REMOTE SENSOR DATA.," U S Geol Surv, Prof Pap, no. 964, 1976.

[46] USDA-SCS, "Sediment Sources, Yields, and Delivery Ratios," In National engineering handbook, section (Vol. 3, pp. 5e6). Washington, DC: United States Department of Agriculture, Sedimentation., 1972.

[47] K. Wolka, J. Mulder, and B. Biazin, "Effects of soil and water conservation techniques on crop yield, runoff and soil loss in Sub-Saharan Africa: A review," Agricultural Water Management, vol. 207. 2018. doi:

10.1016/j.agwat.2018.05.016.

[48] Q. Wang et al., "Runoff and nutrient losses in alfalfa (Medicago sativa $\mathrm{L}$ ) production with tied-ridge-furrow rainwater harvesting on sloping land," International Soil and Water Conservation Research, 2021, doi: 10.1016/j.iswcr.2021.09.005.

[49] L. Sun, J. L. Zhou, Q. Cai, S. Liu, and J. Xiao, "Comparing surface erosion processes in four soils from the Loess Plateau under extreme rainfall events," International Soil and Water Conservation Research, vol. 9, no. 4, 2021, doi: 10.1016/j.iswcr.2021.06.008.

[50] D. A. Bekele, G. W. Gella, and M. A. Ejigu, "Erosion risk assessment: A contribution for conservation priority area identification in the sub-basin of Lake Tana, north-western Ethiopia," International Soil and Water Conservation Research, 2021, doi: 10.1016/j.iswcr.2021.04.010. 
[51] T. Gashaw, T. Tulu, and M. Argaw, "Erosion risk assessment for prioritization of conservation measures in Geleda watershed, Blue Nile basin, Ethiopia,"

Environmental Systems Research, vol. 6, no. 1, 2018, doi: 10.1186/s40068-016-0078-x.

[52] M. Osman and P. Sauerborn, "Soil and water conservation in Ethiopia experiences and lessons," Journal of Soils and Sediments, vol. 1, no. 2, 2001, doi:

10.1065/jss2001.06.014.

[53] C. M. Fayas, N. S. Abeysingha, K. G. S. Nirmanee, D. Samaratunga, and A. Mallawatantri, "Soil loss estimation using RUSLE model to prioritize erosion control in KELANI river basin in Sri Lanka," International Soil and Water Conservation Research, vol. 7, no. 2, pp. 130-137, 2019, doi: 10.1016/j.iswcr.2019.01.003.

[54] T. Amsalu and A. Mengaw, "GIS-Based Soil Loss Estimation Using RUSLE Model: The Case of Jabi Tehinan Woreda," Natural Resources, pp. 616-626, 2014.

[55] D. Lakew, K. Menale, and J. Pender, "Land Degradation and Strategies for Sustainable Development in the Ethiopian highlands: Amhara Region, Socio-economics and Policy Research Working Paper," no. 32, p. 122, 2000.

[56] N. Haregeweyn et al., "Comprehensive assessment of soil erosion risk for better land use planning in river basins: $\mathrm{A}$ case study of the Upper Blue Nile River," Science of the Total Environment, vol. 574, pp. 95-108, 2017, doi: 10.1016/j.scitotenv.2016.09.019.

[57] E. Yeshaneh, J. L. Salinas, and G. Blöschl, "Decadal Trends of Soil Loss and Runoff in the Koga Catchment, Northwestern Ethiopia," Land Degradation and Development, vol. 28, no. 6, pp. 1806-1819, 2017, doi: 10.1002/ldr.2375.

[58] A. Y. Yesuph and A. B. Dagnew, "Soil erosion mapping and severity analysis based on RUSLE model and local perception in the Beshillo Catchment of the Blue Nile Basin, Ethiopia," Environmental Systems Research, vol. 8 no. 1, pp. 1-21, 2019, doi: 10.1186/s40068-019-0145-1.

[59] B. Gessesse, W. Bewket, and A. Bräuning, "Model-Based Characterization and Monitoring of Runoff and Soil Erosion in Response to Land Use/land Cover Changes in the Modjo Watershed, Ethiopia," Land Degradation and Development, vol. 26, no. 7, pp. 711-724, 2015, doi: 10.1002/ldr.2276.

[60] H. K. Addis, S. Strohmeier, F. Ziadat, N. D. Melaku, and A Klik, "Modeling streamflow and sediment using SWAT in Ethiopian highlands," International Journal of Agricultural and Biological Engineering, vol. 9, no. 5, pp. 51-66, 2016, doi: 10.3965/j.jjabe.20160905.2483. 